IZA DP No. 6866

Constrained Firms, Not Subsistence Activities:

Evidence on Capital Returns and Accumulation in Peruvian Microenterprises

Kristin Göbel

Michael Grimm

Jann Lay

September 2012 


\title{
Constrained Firms, Not Subsistence Activities: Evidence on Capital Returns and Accumulation in Peruvian Microenterprises
}

\author{
Kristin Göbel \\ University of Hamburg \\ Michael Grimm \\ University of Passau, \\ Erasmus University Rotterdam, IZA, DIW \\ Jann Lay \\ University of Göttingen, \\ GIGA German Institute of Global and Area Studies, Hamburg \\ Discussion Paper No. 6866 \\ September 2012 \\ IZA \\ P.O. Box 7240 \\ 53072 Bonn \\ Germany \\ Phone: +49-228-3894-0 \\ Fax: +49-228-3894-180 \\ E-mail: iza@iza.org
}

Any opinions expressed here are those of the author(s) and not those of IZA. Research published in this series may include views on policy, but the institute itself takes no institutional policy positions. The IZA research network is committed to the IZA Guiding Principles of Research Integrity.

The Institute for the Study of Labor (IZA) in Bonn is a local and virtual international research center and a place of communication between science, politics and business. IZA is an independent nonprofit organization supported by Deutsche Post Foundation. The center is associated with the University of Bonn and offers a stimulating research environment through its international network, workshops and conferences, data service, project support, research visits and doctoral program. IZA engages in (i) original and internationally competitive research in all fields of labor economics, (ii) development of policy concepts, and (iii) dissemination of research results and concepts to the interested public.

IZA Discussion Papers often represent preliminary work and are circulated to encourage discussion. Citation of such a paper should account for its provisional character. A revised version may be available directly from the author. 


\section{ABSTRACT \\ Constrained Firms, Not Subsistence Activities: Evidence on Capital Returns and Accumulation in Peruvian Microenterprises ${ }^{*}$}

We investigate the returns to capital and capital accumulation using panel data of Peruvian micro enterprises (MEs). Marginal returns to capital are found to be very high at low levels of capital, but rapidly decreasing at higher levels. The dynamic analyses of capital accumulation in MEs suggest that credit constraints explain a major part of the variation in firm growth. We find a very large positive effect of household non-business wealth on capital stocks of MEs. We also show a sizable effect of risk on accumulation and pronounced interactions between wealth and risk. The presented evidence is consistent with poorly endowed entrepreneurs who operate in imperfect capital markets and a very risky environment.

JEL Classification: D13, D61, O12

Keywords: micro and small enterprises, credit constraints, risk, risk aversion, firm growth, Peru

Corresponding author:

Michael Grimm

Chair of Development Economics

University of Passau

Innstraße 29

94032 Passau

Germany

E-mail: michael.grimm@uni-passau.de

\footnotetext{
* This research is part of a project entitled "Unlocking potential: Tackling economic, institutional and social constraints of informal entrepreneurship in Sub-Saharan Africa" (http://www.iss.nl/informality) funded by the Austrian, German, Norwegian, Korean and Swiss Government through the World Bank's Multi Donor Trust Fund Project: "Labor Markets, Job Creation, and Economic Growth, Scaling up Research, Capacity Building, and Action on the Ground". The financial support is gratefully acknowledged. The project is led by the International Institute of Social Studies of Erasmus University Rotterdam, The Hague, The Netherlands. The other members of the research consortium are: AFRISTAT, Bamako, Mali, DIAL-IRD, Paris, France, the German Institute of Global and Area Studies, Hamburg, Germany and the Kiel Institute for the World Economy, Kiel, Germany.

We thank participants at the 6th IZA/World Bank Conference: Employment and Development in Mexico City, the Development Economics Conference 2011 of the German Economic Association in Berlin, and the UNU-WIDER Nordic Conference in Development Economics 2011 in Copenhagen for useful comments and suggestions.
} 


\section{Introduction}

Income from microenterprises (MEs) constitutes the main livelihood of the growing number of poor urban dwellers in developing countries. It is widely assumed that some of these MEs may not realize their full earnings potential due to limited access to credit. This assumption provides the rationale for a key policy intervention towards MEs, micro-credit programs. Several empirical studies have found very high marginal returns to capital in MEs in poor countries - typically well above market interest rates, and in some studies highest at very low levels of capital stock (Fafchamps et al., 2011; Grimm, Krüger, and Lay, 2011; Kremer, Lee, and Robinson, 2010; McKenzie and Woodruff, 2006; Udry and Anagol, 2006). This finding hints indeed at credit constraints as one major obstacle to firm growth. Otherwise, a profit-maximizing entrepreneur would increase the capital stock until marginal returns equalize the market interest rate. Empirical work that explicitly addresses credit constraints also confirms their importance (De Mel, McKenzie, and Woodruff, 2008; De Mel, McKenzie, and Woodruff, 2012; McKenzie and Woodruff, 2008). Yet, credit constraints may only partly explain the observed high returns to capital. In fact, the persistence of small-scale activities in many poor countries is difficult to reconcile with very high returns to capital only caused by credit constraints. Successful entrepreneurs should be able and willing to re-invest a part of their high returns into their $\mathrm{ME}$, thereby overcoming credit constraints and accumulating capital (as shown, for example, by Tybout, 1983). Risk may be the reason why this is not the case, as optimal capital stocks may be much lower than in less risky environments. The empirical literature generally has difficulties in the operationalization of risk and risk attitudes, which may explain why so far empirical research on the role of risk for ME performance is scarce. An exception is De Mel et al. (2008) who do, however, not find any sizeable effect of risk on returns to capital. Nevertheless, there is indirect evidence of the role of risk, such as the high rates of churning among informal MEs in developing countries (Mead and Liedholm, 1998).

This paper aims at providing new empirical insights on the returns to capital, and the dynamics of small-scale activities in developing countries. We use a unique panel dataset of Peruvian MEs covering the period 2002 to 2006. The analysis of the ME sector is particularly relevant in the case of Peru, as these firms account for about 75 percent of employment in this country. Even during the impressive growth period covered by our panel, with growth 
averaging 5.7 percent per annum, there has been no decline in employment in MEs. To test whether we can confirm previous findings of high returns for MEs, we first estimate production functions. In addition, we use this step to compute total factor productivities and an idiosyncratic risk proxy. We then examine capital accumulation. Our main contribution is hence to complement the static investigation of high returns to capital by a dynamic analysis of the determinants of capital accumulation. The focus will be on two fundamental constraints to capital growth in MEs, credit constraints and risk.

The remainder of the paper is organized as follows. The subsequent section provides a brief overview of previous evidence on ME performance and the constraints they face. In Section three, we present some theoretical considerations. Section four describes the dataset and the basic characteristics of Peruvian micro-entrepreneurs and their enterprises. Section five presents our empirical setup and discusses the results. The final section summarizes our main findings and concludes.

\section{Previous evidence}

There is now quite some evidence for very high returns to capital in small-scale activities in developing countries (De Mel, McKenzie, Woodruff, 2008; Fafchamps et al., 2011; Grimm, Krüger and Lay, 2011; Kremer, Lee, and Robinson, 2010; McKenzie and Woodruff, 2006; McKenzie and Woodruff, 2008; Udry and Anagol, 2006). De Mel et al. (2008), for instance, perform an experiment in which they randomly provide cash or in-kind transfers to Sri Lankan MEs. The authors find, at least for male entrepreneurs, marginal returns to capital in a range from 55 to 70 percent per year. Consistent with credit market constraints, the marginal returns to capital are lower (higher) for wealthier (poorer) entrepreneurs. No significant differences in marginal returns between risk-averse and less risk-averse entrepreneurs can be detected. In a similar experiment in Mexico, McKenzie and Woodruff (2008) also provide evidence of very high returns of at least 20-33 percent a month. Returns are - with up to 100 percent monthly - highest among firms with capital stocks near \$200 that report being financially constrained. At least for this selected group, there is hence a strong indication for credit market imperfections causing high returns at low levels of capital. $^{i}$ 
Whereas these fairly recent empirical studies focus on returns to capital and their causes, there is a separate strand of the literature that examines the patterns of entry, exit, and growth of MEs. Mead and Liedholm (1998) summarize the findings of a research project on ME behavior which draws (partly) on panel datasets from a number of developing countries. The authors typically find high rates of churning among MEs, with survival being positively associated with firm age, smaller initial size and past growth. The analysis of firm growth shows that MEs, which were smaller at start-up, tend to grow more rapidly than their larger counterparts. Moreover, young firms grow faster.i These results are similar to those obtained by Fajnzilber, Maloney, and Montes-Rojas (2006) using Mexican data. These authors find that size and time in business are negatively related to exit and growth. They conclude that MEs in Mexico show dynamic patterns consistent with a number of standard results from the theoretical literature on firm dynamics.

While Mead and Liedholm (1998) and Fajnzilber et al. (2006) describe quite well some dynamic features of MEs in developing countries, they have little to say on the causes of differences in behavior.iii Few studies explicitly show the impact of capital constraints on accumulation. One exception is a study about the garment industry in Tirupur in Southern India by Banerjee and Munshi (2004). The authors find large and systematic differences in the level of capital stock in firms owned by people from two different community groups. This finding may be attributed to differences in access to capital between the groups. One of them, the Gounders, comes from a relatively wealthy agricultural community that was the first to move into the garment industry in Tirupur. Banerjee and Munshi (2004) argue that the incumbent Gounders start their businesses with much higher levels of capital stock than comparable outsiders because of their stronger ties to the local community, and the associated better access to finance. Both groups accumulate capital over time, but the outsiders do so much faster to catch up with the Gounders after approximately seven years. $^{\text {iv }}$

Recent work by de Mel et al. (2012) - again based on the sample of Sri Lankan MEs examines the long-term effects of a (randomly assigned) transfer of cash or capital. Tracking MEs over a period of 4.5 to 5.5 years they show that these transfers lead to permanently higher capital stocks and, accordingly, higher profits in treated MEs. De Mel et al. (2012) interpret these findings as an indication of tight credit constraints. Yet, the lack of reinvestment of profits by the control group suggests that other factors must be at work as 
well. De Mel et al. (2012) point at behavioral factors, in particular the lack of self-control and time-inconsistent preferences, as a possible explanation why MEs do not accumulate capital - despite possibly high returns to investment.

\section{Theoretical considerations}

In this section, we briefly illustrate how credit constraints and risk explain the high returns to capital, as well as their possible impacts on capital accumulation. This allows us to derive some hypotheses which will be tested subsequently.

Take a standard neoclassical production function

$$
Y_{t}=F\left(K_{t}, L_{t}, \Omega_{t}\right)
$$

where $Y_{t}$ is production of firm $i$ in period $t, K_{t}$ and $L_{t}$ are inputs of capital and labor, and $\Omega_{t}$ is the efficiency level or total factor productivity (TFP). Firm indices have been suppressed for brevity. Under neoclassical assumptions on the production technology, returns to capital are higher at lower levels of capital. This leads to the question why the capital stock of MEs may be low.

Assuming that the capital stock $K_{t}$ follows a standard accumulation function, it is consequently the start-up capital $K_{0}$ plus the sum of all investments $I_{t-j}$ minus depreciation. This yields:

$$
\begin{aligned}
K_{t} & =(1-d) K_{t-1}+I_{t-1} \\
\Leftrightarrow K_{t} & =(1-d)^{t} K_{0}+\sum_{j=1}^{t}(1-d)^{t-j} I_{t-j},
\end{aligned}
$$

where $d$ denotes the depreciation rate. We further assume that $K_{0}$ and $I_{t}$ are determined by the following reduced form equations

$$
\begin{aligned}
& K_{0}=K\left(\Omega_{0}^{e}, W_{0}, R_{0}\right) \\
& I_{t}=I\left(K_{t}, \Omega_{t}, W_{t}, R_{t}\right),
\end{aligned}
$$

where $\Omega_{0}^{e}$ is the expected productivity in $t=0, W_{t}$ denotes the wealth level to proxy for credit constraints, and $R_{t}$ is risk.

In a simple neoclassical world without frictions, the start-up capital stock will be the optimal capital stock that needs to be maintained over time. It would be chosen to equate the 
market interest rate to marginal returns to capital - given expected productivity (equation (3)). Yet, under credit constraints and in the presence of risk the start-up capital of firms may be lower. Information asymmetries and moral hazard that cause credit market failure are typically exacerbated in developing economies, and more so for MEs." Informal entrepreneurs with different capacity to provide collateral may therefore face different costs of capital. This in turn implies that some entrepreneurs are not able to realize the desired (initial) capital stock.

Similar to credit constraints, risk drives a wedge between market interest rates and marginal returns, as risk-averse entrepreneurs demand a risk premium on their invested capital stock. The reason for the lower capital stocks is not the capital cost that the entrepreneurs face, but the higher shadow value that risk-averse entrepreneurs attach to risky profits. Fafchamps (1999) notes that in such a risky environment without appropriate contractenforcing formal institutions, true business risk is likely to be compounded by opportunistic and contractual risk. The argument is that high exposure to risk makes it easy to falsely claim inability to comply with contractual obligations towards a business counterpart. ${ }^{\text {vi }}$

Entrepreneurs adjust their capital stock over time (equation (4)). Very importantly, firms can overcome credit constraints by retaining earnings (Evans and Jovanovich, 1989; Cabral and Matá, 2003). Capital stocks would then be increasing with enterprise age. If a firm produces under a neoclassical production function, marginal returns to capital are higher at low levels of capital stock. For firms with sub-optimal levels of capital stocks incentives for investment are hence higher the smaller the capital stock. Similarly, incentives are stronger and the capacity to retain earnings higher, the more productive a firm is. Younger and more productive firms will consequently be able to accumulate faster.

The dynamic implications of risk are more complex. In risky environments, risk-averse entrepreneurs require a risk premium on additional investment and may postpone it (Dixit and Pindyck, 1994). Risk should then have a negative impact on capital accumulation. Yet, new information or learning may decrease uncertainty (Jovanovic, 1982). The risk premium will then decrease over time and accumulation will (ceteris paribus) be faster in older firms.

Finally, risk and credit constraints interact. One important interaction may be that less wealthy and, hence, credit-constrained entrepreneurs may be more risk averse and, consequently, exhibit a lower propensity to invest. Generally, more risk averse 
entrepreneurs value foregone investment due to credit constraints less (the shadow value of risky profits is lower for them). This implies that their incentives for additional investment out of withheld profits are also lower, and, ceteris paribus, their pace of capital accumulation lower. Furthermore, if firm owners face credit constraints and investments are partly irreversible, they may have strong motives for precautionary savings. Only when the level of precautionary savings is deemed comfortable enough, risky investments will be undertaken (Fafchamps and Pender, 1997; Fafchamps, 1999). Interaction between wealth and risk may also manifest themselves in (endogenous) time-inconsistent preferences. Very high discount rates are typically observed for low-wealth individuals in high-risk environments (Pender,1996; Yesuf and Bluffstone, 2008). ${ }^{\text {vii }}$

The considerations above lead to the following hypotheses to be tested subsequently: (i) returns to capital are high in MEs - if these firms operate under credit constraints and risk; (ii) credit constraints and risk reduce initial capital stocks and result in a slower pace of capital accumulation; (iii) the impact of both risk and credit constraints on accumulation decreases with higher enterprise age.

\section{Data and ME characteristics}

We use data from the nationally representative Peruvian household survey (ENAHO) collected by the National Institute of Statistics and Informatics (INEI) between 2002 and 2006. The ENAHO comprises around 20,000 households each year, and it entails a panel subsample of about 5,000 to 6,000 households (again nationally representative) of which $55-80$ percent are re-visited in the following year (see Table A1 in the appendix). ${ }^{\text {vii }}$ The survey provides detailed information on individual socio-demographic and employment characteristics. Individuals who are identified as independent workers or as employers (in principal or secondary employment), and who are not working in agriculture, livestock production, or forestry, are interviewed in an Informal Sector Module. ${ }^{\text {ix }}$ This module captures the characteristics of the entrepreneurs and their production unit in MEs with up to ten employees. It also contains detailed information on input use and sales and the legal status of the firm as well as characteristics of employed workers. We restrict our analysis to individuals in urban areas, i.e. in cities with at least 4,000 inhabitants. Furthermore, we exclude ME observations with either missing or non-positive values for the variables used 
(value-added, labor and capital), as well as MEs in the primary sector. The final dataset for estimation is an unbalanced panel of MEs with 2,825, 1,006, 439, 283, and 135 MEs, which we observe in one, two, three, four and five years, respectively.

Table 1 illustrates the employment structure of the labor force in the panel sub-sample. The importance of the informal sector is remarkable, even compared to Latin American averages. More than a third of the Peruvian workforce is self-employed. Another almost 30 percent work as paid worker in informal firms, defined as firms without registration or written accounts, or as unpaid family workers. Compared to men, women are less likely to be wageemployed and more often engaged as unpaid family worker.

[Table 1 about here]

Some basic characteristics of Peruvian MEs from the Informal Sector Module are highlighted in Table 2. MEs are typically very small with a mean firm size of 1.6 including the owner. Almost one third of the firms operate with the help of unpaid family members and only 12 percent employ paid staff. The average enterprise age of about 8 years is higher than one might probably expect. The ME owner is, on average, 42 years old and has been to school for 10 years. Almost half of the owners are female. Incomes from MEs are fairly low, with mean and median monthly value-added of about 150 and 90 US Dollar (USD). ${ }^{x}$ The median capital stock of USD 80 suggests that most activities do not require much investment. On the other hand, a mean capital stock of USD 700 implies that some firms have relatively high capital stocks. Most MEs can be found in petty trading (38 percent) followed by transport (15 percent), hotels and restaurants (13 percent), and other manufacturing \& food (13 percent). The different industries are very heterogeneous in many characteristics, for example in capital stocks, gender-composition, or number of employees.

[Table 2 about here]

Data presented in Table 2 show that MEs are being established and closed at a substantial rate. Depending on the industry, new starts during the year account for 24-38 percent of all 
existing firms. Similarly, of all observed firms between 26 and 42 percent close every year. ${ }^{\mathrm{xi}}$ Entry (as well as exit) rates are higher in sectors that require less capital. New firms start with a 30 percent lower median capital stock on average. Capital accumulation is quite heterogeneous as well; for example, MEs in wholesale/retail shops - on average - even reduce their capital stock (see Table 1 ).

Figure 1 provides another indication that Peruvian MEs tend to adjust their capital stocks over time. Based on a sample of firms with a maximum age of three years when first observed, this figure shows the capital stock (year effects controlled) of MEs that can be found in the first and fourth quartile of the distribution of initial capital stocks, respectively. ${ }^{\text {xi }}$ The initial difference in capital stocks between these two groups is very large. Firms in the fourth quartile start with a log capital stock that is almost four times higher than from those in the first quartile. This implies that the capital stock is more than 50 times higher in this group. Yet, MEs that start with lower capital stocks accumulate, while those with a high capital stock even tend to reduce their capital stocks. After 3 years, capital stocks in the two groups still differ significantly. Nevertheless, the log difference has reduced to about 2.5 implying that capital stocks in firms with high initial capital stocks are only about ten times larger than in the group that starts with low levels.

[Figure 1 about here]

\section{Empirical analysis}

\subsection{Capital returns}

We first estimate a production function to test whether we can find high returns to capital in Peruvian MEs. For estimation purposes we take a log-linear transformation of the production function (1):

$$
\begin{aligned}
& y_{i t}=\alpha_{i}+\beta l_{i t}+\gamma k_{i t}+u_{i t} \\
& u_{i t}=\omega_{i}+\varepsilon_{i t}
\end{aligned}
$$

with lower case letters referring to log values of value-added, labor, and capital of firm $i$ at time $t$, respectively. ${ }^{\text {xii }}$ The error term $u_{i t}$ may be decomposed into two components: $\varepsilon_{i t}$, an 
i.i.d. error term and $\omega_{i}=\ln \left(\Omega_{\mathrm{i}}\right)$. To estimate the production function for each industry, a random effects $(\mathrm{RE})$ panel model is employed. A RE regression gives unbiased estimates only if the individual effect $\omega_{i}$ influences value-added directly. However, it may also simultaneously determine input factor use which may bias our coefficients. Multiple ways to address the simultaneity problem have been proposed, including a fixed effects (FE) estimator, semiparametric proxy estimators and GMM system estimation. The latter requires at least three time periods, which is not feasible as it would reduce our sample by more than 60 percent. Similar problems plague the FE-estimator and the semiparametric proxy estimator proposed by Levinsohn and Petrin (2003) (henceforth LP). The semiparametric LP estimator uses within-plant changes in intermediate/electricity inputs as a proxy for productivity shocks. Unfortunately, about 15 percent (66 percent) of all MEs in our sample do not use intermediate (electricity) inputs, and would be excluded from the analysis. The FE estimator uses only the variation within firms over time. It is unbiased under the assumption of the unobserved firm-specific productivity being time-invariant. Yet, there are several weaknesses. Using only the within variation, coefficients reflect marginal productivities which implies that potential start-up costs are ignored. More importantly, FEestimators perform poorly in short panels, a feature which is well known in the literature. As the within-variation tends to be much lower than the cross-sectional variation, $\mathrm{FE}$ coefficients are often weakly identified, and consequently biased towards zero. This problem is aggravated by measurement error. All of these factors should result in a strong downward bias of the estimates. Hence, we opt for applying the FE and LP estimators only as a robustness check (results provided in section 5.3).

Table 3 presents the production function estimates as well as the implied marginal returns to capital. The estimated coefficients are very much in line with previous studies with a log labor coefficient in the range between 0.5 and 0.7 , and a log capital coefficient between 0.1 and 0.2. ${ }^{\text {xiv }}$ There is quite some sectoral variation, in particular in the capital coefficient. The differences in the sector specific R2s also suggest that there is a lot of heterogeneity in the within sector variance of returns, probably partly driven by differences in the extent of reporting errors. The output-capital elasticity is highest in manufacturing (0.22) and lowest in petty trading (0.08). With an average of 14 percent, monthly returns to capital are very high, but also very heterogeneous. In the most capital intensive sector transport the returns are rather low with only 2 percent, while they amount to 80 percent in the least capital 
intensive sector construction. If an entrepreneur invests an additional USD 10 USD into her $\mathrm{ME}$, monthly income increases by USD 6.8 in construction, and only by USD 0.2 in transport. To relate these results on marginal returns to income levels of the entrepreneurs: At mean value-added and capital stock these marginal returns would correspond to a permanent income gain of 6 percent in construction, but only 0.1 percent in transport.

[Table 3 about here]

Figure 2 presents the returns to capital as a function of the capital stock based on the estimates presented in Table 3 (for all industries). Except for the capital stock, we take mean values in all other variables. As previous studies, our analysis of returns to capital in Peruvian MEs shows very high marginal returns to capital that decline rapidly as firms accumulate capital. Yet, in a range up to 130 USD of capital stock marginal returns are well above 10 percent monthly. More than 57 percent of MEs can be found in this range and may hence be able to realize these returns if provided the necessary capital. As laid out above, the lack of credit may, however, not be the single reason for low capital stocks and unexploited opportunities. Risk may also cause lower investment and hence lower capital stocks.

[Figure 2 about here]

\subsection{Capital accumulation}

In this section, we attempt to identify the factors that restrict capital accumulation. In accordance with our theoretical considerations, we first examine the determinants of the start-up capital stock. The investment equation (3) then takes the following functional form:

$$
k_{\mathrm{i} 0}=\mu_{1}+\mu_{2} \Omega_{i t}^{e}+\mu_{3} W_{\mathrm{i} 0}+\mu_{4} R_{\mathrm{i} 0}+\mu_{5} R_{\mathrm{i} 0} W_{\mathrm{i} 0}+e_{\mathrm{i} 0}
$$

In a second step, we analyze the accumulation behavior:

$$
\Delta k_{i t}=\rho_{0} k_{i t}+\rho_{1}+\rho_{2} \Omega_{i t}+\rho_{3} W_{i f}+\rho_{4} R_{i t}+\rho_{5} R_{i t} W_{i f}+u_{i t} .
$$


All variables are defined as before, $e_{i 0}$ is an error term, and $u_{i t}$ is the combined error term. Capital growth $\Delta k_{i t}$ is measured as the change in log capital $\left(k_{i t+1}-k_{i t}\right)$. The term $R_{i t} W_{i f}$ is the interaction between risk and wealth (from the first observed period in business). We now briefly discuss the key right-hand-side variables and how we proxy them: credit constraints, productivity, and risk. Their distributions as well as means and standard deviations are presented in Figure $\mathrm{A} 1$ in the appendix.

The expected productivity is proxied by owner's age and its square, years of education, and a dummy for male entrepreneurs. In equation (7), productivity $\Omega_{i t}$ is measured as the time invariant residual $\omega_{i}$ obtained by a RE estimation of the production function (5).

Credit constraints are proxied by the wealth level $W_{i f}$ of the household, as household assets may serve as collateral for credit. The household wealth index is derived from the first principal component of a set of indicators of ownership of household assets. The latter include only non-business assets, such as color televisions and the condition of the house, for example the state of the walls and the quality of sanitary facilities. Household wealth, however, may be correlated with unobservable characteristics, such as entrepreneurial ability or motivation, which also affect the start-up capital stock and growth. This correlation is likely to be positive implying an upward bias of the estimated coefficient. This potential bias should be somewhat reduced by including the above proxies (age, education, gender) for expected productivity in equation (6) and the productivity measure in equation (7). Possible problems of reverse causality are addressed in equation (7) by using for the wealth index the information on asset ownership provided in the first observed period in business $\left(W_{i f}\right)$.

Risk is difficult to operationalize. Yet, we propose to construct a series of proxies. First, we measure risk by the variation of sales, a "classical" proxy for risk. We compute this variation at the sector level with sectors being disaggregated as finely as possible while keeping the number of observations in each sector cell at least at 30 . To this end, we use the pooled cross-sectional sample with almost four times as many observations that allows for a finer disaggregation. Such a procedure yields 85 sector cells, for which we compute the coefficients of variation in sales. 
Second, we propose to measure idiosyncratic risk using the time-variant component from the FE estimation of equation (5). More specifically, we construct a measure of exposure to risk $R E S_{i}$ from the residual $\varepsilon_{i t}$ :

$$
R E S_{i}=\sum_{t=1}^{T}\left|\varepsilon_{i t}\right| / T_{i}
$$

where $T_{i}$ refers to the number of periods, in which we observe the ME $i .{ }^{\mathrm{xv}}$ This measure, based on average absolute time-variant FE residuals, reflects only firm-specific volatility in value-added observed over the lifespan of the ME. ${ }^{\text {xvi }}$ It captures the ex-ante effects of anticipated shocks and cyclical effects as well as possibly non-anticipated ex-post effects of shocks. We argue above that we prefer RE over FE since the latter performs poorly in short panels and the coefficients are downward biased. This implies an overestimation of the productivity level $\omega_{i}$ and, more importantly, a strong correlation with the input factors. Yet, it is difficult to say whether and how this bias affects the time-variant residuals. By definition these residuals sum up to zero for each firm. Their estimated variance may, however, be overestimated, for example if too much of possible anticipated cyclical effects now enter $\varepsilon_{i t}$, in particular since labor coefficients are underestimated. To guard against the importance of such effects we test whether $\varepsilon_{i t}$ is correlated with input use; and it turns out that this correlation is very low $(<0.05)$.

Third, we can average $R E S_{i}$ at the sector-level (49 sector cells, if only the panel data is used). Fourth, we use the share of entrepreneurs that are found to be unemployed, helping as unpaid family worker, or even leaving the labor force in the subsequent period to construct a sector-specific involuntary exit rate (45 sector cells of the panel). ${ }^{\text {xvii }}$ Except $R E S_{i}$ all risk proxies are measured at the sector level, and are constant over time. We opt for using sector-cells rather than sector-year cells to measure sector-specific risk. This permanent risk measure is constant over time, and it is likely to be more relevant than temporary risk shocks for investment decisions. Moreover, it allows a finer sector disaggregation.

We report the pairwise correlations of these risk proxies in Table A2 in the appendix. In line with expectations, all correlations are positive. It is difficult to judge which of these imperfect proxies is most adequate; and they may be capturing different dimensions of business risk. Due to the correlation between the single proxies they cannot be included jointly in a regression. From a combination of these proxies, we therefore propose to construct a risk proxy using principal components analysis (see Table A2 in the appendix). 
The first principal component that we will use as risk proxy in the subsequent analysis explains about 38 percent of the "total variance" in the four variables (53 percent without the idiosyncratic $\left.R E S_{i}\right)$.

With our right-hand side variables specified, we now analyze the determinants of the startup capital stock. The first column of Table 4 presents the OLS estimation results of equation (6). The sample is restricted to start-up MEs defined as being owned by entrepreneurs who did not have a firm in the previous year. In line with the theoretical considerations, asset-rich entrepreneurs start with a considerably higher capital stock. An increase in the wealth level by 1 standard deviation raises the capital stock by 46 percent from 60 to 88 USD for a hypothetical ME with mean values. Risk is associated with a lower initial capital stock. ${ }^{\text {xviii }}$ If the risk exposure of our hypothetical firm decreases by 1 standard deviation, its capital stock is 90 percent higher and amounts to 114 USD. Furthermore, the interaction term of wealth and the risk proxy has a positive coefficient, i.e. at higher levels of wealth the negative effects of risk are mitigated. An alternative reading would be that credit constraints are less binding in risky environments where risk-averse entrepreneurs attach less value to foregone profits.

The second and third columns present the results from the RE accumulation regression. ${ }^{\text {xix }}$ The most important factor appears to be the pre-investment capital stock, i.e. small MEs grow considerably faster. An increase in the capital stock by 1 percent leads to an approximate decrease of the growth rate of 0.5 percentage points. As expected, productivity also fosters accumulation, an increase by 1 standard deviation results in an increase of the growth rate by 13 percentage points. Young firms appear to grow faster with a turning point at a relatively high enterprise age of 28 years. , This is in line with previous evidence and may be partly due to depreciation of a capital stock that is not being renewed or replaced (Mead and Liedholm, 1998; Faijnzilber et al., 2006). These (pure) age effects are rather small; the growth rate of an ME declines by about 3 percentage points with one additional year of existence.

In contrast, the effects of credit constraints and risk on investment tend to be very large. Both coefficients are highly significant and the implied effects sizable: An increase in the wealth level by 1 standard deviation raises the growth rate by 33 percentage points. If risk decreases by 1 standard deviation, the growth rate is 39 percentage points higher ceteris 
paribus. ${ }^{x x}$ The interaction term between risk and wealth has the expected positive sign, a finding consistent with more wealthy entrepreneurs being less risk averse. Comparing an entrepreneur with average wealth to a wealthy (average plus 1 standard deviation) entrepreneur, the increase in the growth rate due to a risk reduction by 1 standard deviation drops by a third.

Finally, we include interactions between enterprise age and the constraint proxies (last column of Table 4). The effects are as expected. The coefficient of the risk index alone increases and we also find evidence of this effect being reduced slowly over time (only after 51 years it reduces to zero). Similarly, the impact of wealth is stronger and we find a negative wealth age interaction (after 55 years the wealth effect reduces to zero).

Summing up, both risk and credit constraints are key factors for explaining low initial capital stocks and slow capital accumulation in MEs. This suggests that these factors are also behind the high returns to capital that we observe at low levels of capital. The "mitigating" effect of wealth in the presence of risk may point at an important role of behavioral factors (high discount rates, lack of self-control) for investment decisions.

[Table 4 about here]

\subsection{Robustness}

We first provide some robustness checks for our production function estimates and the corresponding estimated returns to capital. Then, we examine the robustness of the results on accumulation with a focus on the effects of risk.

Table 5 presents the LP and FE estimates of the above production function. The LP coefficients on capital are very similar to the RE coefficients, but the labor coefficients are significantly lower. This gives us some confidence that the RE estimates on the capital coefficients are not upward biased, and the returns to capital stated in Table 3 are reliable. Both the FE coefficients on labor and capital are very low, probably reflecting their downward bias due to weak identification and measurement error. 
[Table 5 about here]

In general, measurement error of both profits and capital tends to bias the estimated coefficients towards zero, so this source of bias does not give rise to major concerns in light of the significant strong effects. Moreover, we dropped influential outliers, as explained above. It is difficult to judge whether and how measurement error changes with higher or lower levels of profits and capital stock. We think there is little reason to assume that measurement error is less pronounced at lower levels of capital stocks, which would then partly explain higher returns at lower levels of capital.

Additional biases may arise from systematic firm exit. ME activities with low levels of capital stock are likely to be more vulnerable to shocks. ${ }^{x \times i}$ This bias should be less pronounced in our estimates, as we use an unbalanced panel. Nevertheless, we test for selection effects by first estimating the following equation for firm survival:

$$
P\left(\text { Survival }_{i t}=1\right)=\mathrm{F}\left(\theta k_{i t}+\eta Z_{i t}+\tau I S_{i t}\right)
$$

where $Z_{i t}$ is a vector of variables that proxy productivity (owner's age and its square, years of education, a dummy indicating male entrepreneurs). The term $I S_{i t}$ is a vector of variables that identify survival (see below). We estimate this equation as a simple probit. To correct for the selection problem, we then include the inverse of the mill's ratio in the augmented production function:

$$
y_{i t}=\alpha_{i}+\beta l_{i t}+\gamma k_{i t}+\rho Z_{i t}+\frac{\phi \varphi\left(\widehat{\theta} k_{i t}+\widehat{\eta} Z_{i t}+\hat{\tau} I S_{i t}\right)}{\Phi\left(\widehat{\theta} k_{i t}+\hat{\eta} Z_{i t}+\hat{\tau} I S_{i t}\right)}+u_{i t}
$$

where $\phi$ denotes the standard normal pdf, and $\Phi$ is the standard normal cdf. The difficulty is to find variables that explain survival/exit, but are not correlated with value-added. We use a dummy indicating whether the entrepreneur is 60 years or older, and the number of small children in a household (less than one year old). That both variables may indeed be associated with involuntary business closure is supported by both instruments being jointly significant at the 10 percent level (not shown). ${ }^{x i i}$ In the production function estimates the inverse of the mill's ratios are not significant. Although the capital coefficient is indeed slightly higher once we control for selection, the difference is not significant (not shown). In contrast, the inverse of the mill's ratios are significant in the growth equation. Once we 
control for selection, small firms still grow considerably faster; however, the coefficient is slightly smaller, but not significantly different from the results presented above (not shown). Another potential concern may be the validity of our risk measure that we construct from a combination of imperfect proxies (variation of sales, involuntary exit rate, idiosyncratic risk, and the latter aggregated at the sector level). As robustness check we therefore included each proxy separately and all proxies jointly in the estimations. In equations (6) and (7) all proxies - when included one by one - enter with the expected negative sign and are highly significant (Table A3 in the appendix). Once they are jointly included, only the idiosyncratic risk measure becomes insignificant in equation (7). In the estimation of equation (6) one proxy, idiosyncratic risk within the sector, changes the sign, but is insignificant. These tests give us quite some confidence that our risk measure indeed provides an adequate summary measure of business risks. With respect to the size of the effects of risk, the inclusion of six industry dummies into equations (6) and (7) provides an important additional robustness check, as most risk proxies are constructed at the sector level and may therefore also capture other sectoral effects. ${ }^{\text {xiii }}$ Not surprisingly, the effects of risk are being reduced and may be considered a lower bound estimate (see Table A4 in the appendix). This estimate still implies that a one standard deviation increase in the risk measure leads to a reduction of start-up capital and the growth rate by 16 percent and 15 percentage points respectively. The coefficient and its interaction with wealth remain highly significant, whereas the interaction with enterprise age becomes insignificant. ${ }^{\text {xiv }}$

\section{Conclusion}

In this paper, we analyze returns to capital and capital stock dynamics of MEs using a panel dataset from Peru. We first compute marginal returns to capital based on a random effects estimation of a ME production function. As many previous studies, we find very high marginal returns - on average about 14 percent monthly - at low levels of capital, but these marginal returns decrease rapidly at higher levels. Yet, in a range up to 130 USD of capital stock marginal returns are well above 10 percent monthly. More than 57 percent of MEs can be found in this range and may hence be able to realize these returns if provided the necessary capital. This result is very robust, as shown by the estimation of a number of alternative specifications. The main empirical part of the paper then examines why capital 
stocks remain low and why MEs do not accumulate, for example by re-investing those high returns. Our analysis of the determinants of start-up capital and subsequent capital accumulation confirms the well-established finding in the literature that credit constraints explain a major part of the variation in firm growth. We find a very large effect of household non-business wealth on capital stocks of MEs. An increase in the wealth level by one standard deviation raises the growth rate of MEs by 33 percentage points. While the positive effect of wealth is a standard finding, it provides an interesting benchmark for the effects of risk that the present study - in our view - can show more convincingly than previous studies. We find risk to lead to considerably lower capital stocks and a slow process of capital accumulation. The effect is again sizable with a lower bound estimate that corresponds to 15 percentage points reduction in the growth rate for a one standard deviation increase in our preferred risk proxy. That MEs' investment decisions are heavily influenced by considering risks, is supported by pronounced interactions between wealth and risk. The presented evidence is consistent with poorly endowed entrepreneurs who operate in imperfect capital markets and a very risky environment. Hence, these entrepreneurs forego profitable investments, as they have to withhold liquidity and/or have very high discount rates. The "pure" risk effects may be efficient individual responses to prevailing business risks when insurance markets fail. However, the significant interaction between wealth and risk show that capital market imperfections reinforce the negative effect of risk on accumulation. This is an indication of important inefficiencies and unexploited potential in MEs caused by risk and credit constraints. However, this paper has little to say on how precisely this mechanism works and more research seems to be warranted that addresses these behavioral questions.

In general, the findings once again illustrate the great heterogeneity of informal activities (Cunningham and Maloney, 2001). While these activities may appear residual activities pursued for subsistence at first sight, the dynamics of an important part - if not the majority of the entrepreneurs in the Peruvian context - can be better described by theories of the firm; yet, of firms that operate under severe constraints. From a policy perspective, these results imply that credit constraints and risk leave the potential of many small-scale entrepreneurs unexploited. How these constraints can be overcome is difficult to say on the basis of our results. Of course, the strong effects of wealth provide a rationale for microcredit, but it is beyond the scope of this paper to judge whether efficient modes can be found to allocate capital to MEs in these small quantities. Access to simple savings accounts 
with light credit lines might be a possible solution. Savings accounts may also mitigate the effects of risk that we have identified. Whether such a measure will be effective in reducing the adverse effects of risk, however, depends on the precise nature of risks. In this regard, it is worth stressing that some risk is inherent to any business activity. This is also why more research into how - possibly excessive - risk leads to sub-optimal investment decisions. Moreover, there is scope to analyze how household-related risks, for example health shocks, affect investment decisions. If these risks mattered, providing corresponding insurance, for example health and life insurance, may enhance capital accumulation in MEs. Both the determinants of ME investment behavior and the effectiveness and efficiency of specific policies are hence pertinent research questions since small-scale activities are likely to remain the main income source of the world's poor in decades to come.

\section{Appendix}

[Table $\mathrm{A} 1$ about here]

[Table A2 about here]

[Table $\mathrm{A} 3$ about here]

[Table A4 about here]

[Figure A1 about here] 


\section{References}

Akoten, John E., Yasuyuki Sawada, and Keijiro Otsuka. 2006. "The Determinants of Credit Access and Its Impacts on Micro and Small Enterprises: The Case of Garment Producers in Kenya." Economic Development and Cultural Change, 54(4): 927-44.

Banerjee, Abhijit V., and Esther Duflo. 2004. "Do Firms Want to Borrow More? Testing Credit Constraints Using a Directed Lending Program. “ CEPR Discussion Papers 4681.

Banerjee, Abhijit V., and Kaivan Munshi. 2004. "How Efficiently is Capital Allocated? Evidence from the Knitted Garment Industry in Tirupur." Review of Economic Studies. 71(1): 1942.

Belsley, David A., Edwin Kuh, and Roy E. Welsch. 1980. Regression Diagnostics. New York: Wiley.

Bigsten, Arne, Paul Collier, Stefan Dercon, Marcel Fafchamps, Bernard Gauthier, Jan Willem Gunning, Abena Oduro, Remco Oostendorp, Cathy Patillo, Måns Söderbom, Francis Teal, and Albert Zeufack. 2003. "Credit Constraints in Manufacturing Enterprises in Africa." Journal of African Economies. 12(1): 104-125.

Cabral, Luis .M.B., and José Mata. 2003. “On the Evolution of the Firm Size Distribution: Facts and Theory." American Economic Review 93(4): 1075-1091.

Coad, Alex, and Jaganaddha Pawan Tamvada. 2012. "Firm growth and barriers to growth among small firms in India." Small Business Economics. 39(2): 383-400.

Cunningham, Wendy V., and William F. Maloney. 2001. "Heterogeneity among Mexico's Microenterprises: An Application of Factor and Cluster Analysis." Economic Development and Cultural Change (5): 131-156.

De Mel, Suresh, David McKenzie, and Christopher Woodruff. 2008. "Returns to Capital in Microenterprises: Evidence from a Field Experiment." The Quarterly Journal of Economics. 123(4): 1329-1372.

De Mel, Suresh, David McKenzie, and Christopher Woodruff. 2012. "One-Time Transfers of Cash or Capital Have Long-Lasting Effects on Microenterprises in Sri Lanka." Science. 335: 962-966. 
Dixit, Avinash K., and Robert S. Pindyck. 1994. Investment under Uncertainty. Princeton University Press, Princeton.

Evans, David S., and Boyan Jovanovic. 1989. "An Estimated Model of Entrepreneurial Choice under Liquidity Constraints." Journal of Political Economy 97(4): 808-27.

Fafchamps, Marcel. 1999. "Rural Poverty, Risk, and Development." Report Submitted to the Food and Agricultural Organization.

Fafchamps, Marcel, David McKenzie, Simon Quinn, and Christopher Woodruff. 2011. "When is Capital Enough to Get Female Enterprises Growing? Evidence from a Randomized Experiment in Ghana." Policy Research Working Paper Series 5706, The World Bank.

Fafchamps, Marcel, and John L. Pender. 1997. "Precautionary Saving, Credit Constraints, and Irreversible Investment: Theory and Evidence from Semiarid India." Journal of Business \& Economic Studies, 15(2): 180-194.

Fajnzylber, Pablo, William Maloney, and Gabriel Montes-Rojas. 2006. “Microenterprise Dynamics in Developing Countries: How Similar are They to Those in the Industrialized World? Evidence from Mexico." World Bank Economic Review. 20(3): 389-419.

Grimm, Michel, Jens Krüger, and Jann Lay. 2011. "Barriers to Entry and Returns to Capital in Informal Activities: Evidence from Sub-Saharan Africa." Review of Income and Wealth, 57: 27-53.

Jovanovic, Bojan. 1982. Selection and the Evolution of Industry. Econometrica. 50(3): 649670.

Kremer, Michael, Jean N. Lee, and Jonathan Robinson. 2010. "The Return to Capital for Small Retailers in Kenya: Evidence from Inventories." Mimeo, Harvard University.

Levinsohn, James, and Amil Petrin. 2003. "Estimating Production Functions Using Inputs to Control for Unobservables." Review of Economic Studies. 70(2): 317-341.

McKenzie, David, and Christopher Woodruff. 2006. "Do Entry Costs Provide an Empirical Basis for Poverty Traps? Evidence from Mexican Microenterprises." Economic Development and Cultural Change. 55(1): 3-42.

McKenzie, David, and Christopher Woodruff. 2008. "Experimental Evidence on Returns to Capital and Access to Finance in Mexico." World Bank Economic Review. 22(3): 457-482. 
McPherson, Michael A. 1996. "Growth of micro and small enterprises in southern Africa. Journal of Development Economics." 48(21): 31-54.

Mead, Donald C, and Carl Liedholm. 1998. "The dynamics of micro and small enterprises in developing countries." World Development. 26(1): 61-74.

Pender, John L.. 1996. "Discount rates and credit markets: Theory and evidence from rural India." Journal of Development Economics. 50: 257-296.

Petrin, Amil, Brian P. Poi, and James Levinsohn. 2004. "Production function estimation in Stata using inputs to control for unobservables." Stata Journal. 4(2): 113-123.

Tybout, James R.. 1983. "Credit Rationing and Investment Behavior in a Developing Country." Review of Economics and Statistics. 65: 598-607.

Udry, Christopher, and Santosh Anagol. 2006. "The Return to Capital in Ghana." American Economic Review. 96(2): 388-393.

Westbrook, M. Daniel, and James R. Tybout. 1993. "Estimating Returns to Scale with Large, Imperfect Panels: An Application to Chilean Manufacturing Industries." The World Bank Economic Review. 7(1): 85-112.

Yesuf, Mahmud, and Randy Bluffstone. 2008. "Wealth and Time Preference in Rural Ethiopia." Environment for Development Discussion Paper Series EFD DP 08-16. 


\section{Tables and Figures}

Table 1: Structure of employment in Peru (in percent)

\begin{tabular}{|lrrr|}
\hline & Total & Male & Female \\
\hline $\begin{array}{l}\text { Wage employment } \\
\quad \text { of which in informal }\end{array}$ & 48.70 & 53.25 & 43.05 \\
firms (\%) & 39.96 & 41.56 & 36.27 \\
Self-employment or & 36.16 & 34.28 & 38.49 \\
Employer & 7.99 & 5.54 & 11.04 \\
Unpaid family work & 7.15 & 6.99 & 7.36 \\
Unemployed & 100 & 100 & 100 \\
Total & & & \\
\hline
\end{tabular}

Source: Authors' calculation based on the panel sub-sample from ENAHO. 
Table 2: Descriptive statistics of MEs by industry

\begin{tabular}{|c|c|c|c|c|c|c|c|c|}
\hline Industries & All & $\begin{array}{l}\text { M.\& } \\
\text { food }\end{array}$ & Constr. & $\begin{array}{l}\text { W./R. } \\
\text { shops }\end{array}$ & $\begin{array}{c}\text { Petty } \\
\text { trad. }\end{array}$ & H.\&R. & Tran. & $\begin{array}{l}\text { Oth. } \\
\text { serv. }\end{array}$ \\
\hline \multicolumn{9}{|l|}{ ME characteristics } \\
\hline Employees & 0.63 & 0.82 & 0.65 & 1.12 & 0.68 & 0.91 & 0.13 & 0.45 \\
\hline Self-employed (\%) & 63.2 & 59.8 & 64.5 & 45.2 & 55.9 & 46.2 & 91.0 & 78.3 \\
\hline With paid employees (\%) & 12.1 & 21.3 & 31.5 & 36.7 & 5.8 & 12.2 & 7.7 & 11.1 \\
\hline With unpaid employees (\%) & 31.4 & 32.7 & 20.5 & 39.5 & 41.2 & 49.7 & 4.1 & 16.4 \\
\hline Monthly value-added (mean) & 153 & 148 & 166 & 305 & 134 & 135 & 165 & 168 \\
\hline Monthly value-added (median) & 90 & 81 & 129 & 190 & 72 & 74 & 133 & 76 \\
\hline Capital (mean) & 697 & 823 & 127 & 962 & 217 & 192 & 2396 & 691 \\
\hline Capital (median) & 83 & 115 & 23 & 153 & 41 & 65 & 1610 & 111 \\
\hline Capital (median) (new MEs) & 58 & 65 & 26 & 227 & 29 & 46 & 1251 & 37 \\
\hline Enterprise age & 7.9 & 11.7 & 11.6 & 9.7 & 7.8 & 6.0 & 5.7 & 6.4 \\
\hline Entry rate (\%) & 29.4 & 30.4 & 37.9 & 24.0 & 25.4 & 33.8 & 26.9 & 39.0 \\
\hline Exit rate (\%) & 32.0 & 34.1 & 41.6 & 25.8 & 26.6 & 33.0 & 31.9 & 46.0 \\
\hline \multicolumn{9}{|l|}{ Owner's characteristics } \\
\hline Gender: Male (\%) & 52.1 & 55.5 & 99.8 & 84.0 & 31.7 & 12.3 & 99.8 & 64.6 \\
\hline Owner's age & 41.9 & 44.7 & 42.5 & 40.0 & 43.3 & 43.9 & 37.2 & 38.2 \\
\hline Owner's years of schooling & 10.5 & 10.5 & 10.4 & 11.3 & 9.8 & 9.1 & 11.2 & 12.7 \\
\hline Observations & 7960 & 1026 & 454 & 281 & 2995 & 1051 & 1194 & 959 \\
\hline
\end{tabular}

Source: Authors' calculation based on the panel sub-sample from ENAHO.

Notes: Industries are other manufacturing \& food, construction, wholesale/retail shops, petty trading, hotels and restaurants, transport, and other services. Monetary values are in constant Dec. 2001 Nuevo Sols (using the INEI Consumer Price Index) and converted into US-\$ using the Dec. 2001 nominal exchange rate. 
Table 3: Production function estimates for Peruvian industries

\begin{tabular}{|c|c|c|c|c|c|c|c|c|}
\hline Industries & All & M.\& food & Constr. & $\begin{array}{l}\text { W./R. } \\
\text { shops }\end{array}$ & $\begin{array}{l}\text { Petty } \\
\text { trad. }\end{array}$ & H.\& R. & Tran. & Oth. serv. \\
\hline Log labor & $0.605 * * *$ & $0.619 * * *$ & $0.642 * * *$ & $0.697 * * *$ & $0.582 * * *$ & $0.690 * * *$ & $0.486 * * *$ & $0.558 * * *$ \\
\hline SE & $(0.015)$ & $(0.036)$ & $(0.045)$ & $(0.066)$ & $(0.028)$ & $(0.041)$ & $(0.040)$ & $(0.040)$ \\
\hline Log capital & $0.118 * * *$ & $0.220 * * *$ & $0.141^{* * *}$ & $0.104 * * *$ & $0.080 * * *$ & $0.076 * * *$ & $0.139 * * *$ & $0.142 * * *$ \\
\hline SE & $(0.005)$ & $(0.015)$ & $(0.026)$ & $(0.029)$ & $(0.011)$ & $(0.020)$ & $(0.014)$ & $(0.016)$ \\
\hline Year dummies & Yes & Yes & Yes & Yes & Yes & Yes & Yes & Yes \\
\hline Outlier $^{+}$ & Yes & Yes & Yes & Yes & Yes & Yes & Yes & Yes \\
\hline Average $\mathrm{K}$ & 84 & 87 & 23 & 150 & 39 & 57 & 1115 & 83 \\
\hline Average $Y$ & 101 & 78 & 127 & 228 & 93 & 101 & 150 & 76 \\
\hline Average $\mathrm{Y} / \mathrm{K}$ & 8.8 & 7.2 & 16.1 & 6.2 & 12.2 & 5.3 & 1.7 & 10.1 \\
\hline M. returns & 0.143 & 0.198 & 0.774 & 0.159 & 0.191 & 0.136 & 0.019 & 0.131 \\
\hline R2 overall & 0.39 & 0.57 & 0.47 & 0.49 & 0.25 & 0.45 & 0.34 & 0.38 \\
\hline $\mathrm{N}$ & 7857 & 1012 & 444 & 274 & 2952 & 1039 & 1170 & 944 \\
\hline
\end{tabular}

Source: Authors' calculation based on the ENAHO panel-subsample.

Notes: Robust standard errors in parenthesis $* p<0.10, * * p<0.05, * * * p<0.01{ }^{+}$In all regressions, we drop influential outliers from our sample (and sub-samples) that we identify by the DFITS-statistic obtained from a precedent OLS regression (See Belsley, Kuh, and Welsch, 1980). We use a cut-off-value $|D F I T S|=3 \sqrt{\mathrm{k} / \mathrm{N}}$, with $k$, the degrees of freedom (plus 1 ) and $N$, the number of observations. This reduces the sample by 1-2 percent. Marginal returns to capital $\frac{d Y}{d K}=\gamma * \frac{Y}{K}$ are evaluated at $\mathrm{Y}=\exp (\operatorname{mean}(\log \mathrm{Y}))$ and $\mathrm{K}=\exp (\operatorname{mean}(\log \mathrm{K}))$. 
Table 4: Estimated functions of start-up capital and accumulation

\begin{tabular}{|c|c|c|c|}
\hline \multirow{3}{*}{$\begin{array}{l}\text { Dependent variable: } \\
\text { Log capital }\end{array}$} & \multirow[t]{2}{*}{ start-up $k$} & \multicolumn{2}{|c|}{$\Delta k$} \\
\hline & & $-0.468 * * *$ & $-0.475 * * *$ \\
\hline & & (0.019) & (0.019) \\
\hline \multirow[t]{2}{*}{ Wealth index } & $0.184^{* * *}$ & $0.138 * * *$ & $0.165 * * *$ \\
\hline & $(0.031)$ & $(0.015)$ & $(0.020)$ \\
\hline \multirow[t]{2}{*}{ Risk index ${ }^{++}$} & $-0.507 * * *$ & $-0.256 * * *$ & $-0.305^{* * *}$ \\
\hline & $(0.052)$ & $(0.028)$ & $(0.036)$ \\
\hline \multirow[t]{2}{*}{ Wealth $*$ Risk index ${ }^{++}$} & $0.043^{* *}$ & $0.037 * * *$ & $0.033 * * *$ \\
\hline & $(0.020)$ & $(0.011)$ & $(0.011)$ \\
\hline \multirow[t]{2}{*}{ Enterprise age } & & $-0.028 * * *$ & $-0.028 * * *$ \\
\hline & & $(0.009)$ & (0.009) \\
\hline \multirow[t]{2}{*}{ Enterprise age ${ }^{\wedge} 2$} & & $0.001 * * *$ & $0.001 * *$ \\
\hline & & $\left(2.3 * 10^{\wedge}-4\right)$ & $\left(2.5 * 10^{\wedge}-4\right)$ \\
\hline \multirow[t]{2}{*}{ TFP } & & $0.235^{* * *}$ & $0.234 * * *$ \\
\hline & & $(0.062)$ & $(0.061)$ \\
\hline \multirow[t]{2}{*}{ Enterprise age * Risk index } & & & $0.006^{*}$ \\
\hline & & & $(0.003)$ \\
\hline \multirow[t]{2}{*}{ Enterprise age ${ }^{*}$ wealth } & & & $-0.003^{*}$ \\
\hline & & & $(0.001)$ \\
\hline Year dummies & Yes & Yes & Yes \\
\hline Outlier controlled $^{+}$ & Yes & Yes & Yes \\
\hline R2 & 0.234 & & \\
\hline R2 overall & & 0.195 & 0.203 \\
\hline $\mathrm{N}$ & 1170 & 2443 & 2435 \\
\hline
\end{tabular}

Source: Authors' calculation based on the ENAHO panel-subsample.

Notes: Regression of equation (6) include: a constant, age and its square, years of education, and a dummy indicating male entrepreneurs. Robust standard errors in parenthesis $* p<0.10, * * p<0.05, * * * p<0.01 .^{+}$In all regressions, we drop influential outliers according to the procedure explained under Table $3 .^{++}$In the estimation presented in the first column, the risk index does not contain the idiosyncratic measure as it is only available for new firms that are observed in at least two periods. This would result in a strong selection and reduce our sample by two thirds. 
Table 5: Robustness: LP and FE estimator of the production function.

\begin{tabular}{|llllll|}
\hline & Log labor & & Log capital & & \\
Method & Coefficient & S.E. & Coefficient & S.E. & N \\
\hline LP & $0.386^{* * *}$ & $(0.013)$ & $0.109 * * *$ & $(0.013)$ & 6610 \\
FE & $0.386^{* * *}$ & $(0.021)$ & $0.042^{* * *}$ & $(0.010)$ & 7857 \\
\hline
\end{tabular}

Source: Authors' calculation based on the ENAHO panel-subsample.

Notes: LP estimates are obtained using the Stata procedure developed by Petrin, Poi, and Levinsohn (2004). LP standard errors (S.E.) are bootstrapped with 250 repl.; ${ }^{*} p<0.10, * * p<0.05, * * * p<0.01{ }^{+}$In all regressions, we drop influential outliers according to the procedure explained under Table 3. 
Table A1: Structure of the panel

\begin{tabular}{|lllll|}
\hline Year & Hh. visited & $\begin{array}{l}\text { Hh. not } \\
\text { interviewed }\end{array}$ & $\begin{array}{l}\text { Hh. observed in } \\
\text { previous period }\end{array}$ & Hh. interviewed \\
\hline 2002 & 6257 & 847 &. & 5410 \\
2003 & 4217 & 688 & 3068 & 3529 \\
2004 & 6490 & 1141 & 2787 & 5349 \\
2005 & 6778 & 1469 & 4146 & 5309 \\
2006 & 6593 & 1182 & 4496 & 5411 \\
\hline
\end{tabular}

Source: Authors' calculation based on the panel sub-sample from ENAHO. 
Table A2: Risk proxies, correlation matrix

\begin{tabular}{|lllll|rc|}
\hline & $\begin{array}{c}\text { Sales } \\
\text { variation }\end{array}$ & exit rate & RES $^{+++}$ & RES & Component 1 & Component 1 \\
\hline Sales variation $^{+++}$ & 1.000 & & & & $\mathbf{0 . 5 4 8}$ & $\mathbf{0 . 5 4 0}$ \\
exit rate $^{+++}$ & $0.290^{* * *}$ & 1.000 & & & $\mathbf{0 . 5 9 5}$ & $\mathbf{0 . 5 5 2}$ \\
RES $^{++}$ & $0.311^{* * *}$ & $0.330^{* * *}$ & 1.000 & & $\mathbf{0 . 5 8 8}$ & $\mathbf{0 . 5 9 0}$ \\
RES & $0.051^{* * *}$ & $0.054^{* * *}$ & $0.165^{* * *}$ & 1.000 & - & $\mathbf{0 . 2 3 5}$ \\
\hline
\end{tabular}

Source: Authors' calculation based on the ENAHO panel-subsample.

Notes: ${ }^{*} p<0.10, * * p<0.05, * * * p<0.01 .^{+++}$Variable is measured at the sector level. The last columns on the right show the eigenvector associated to the first component (without and with the idiosyncratic risk). 
Table A3: Risk proxies, regressions

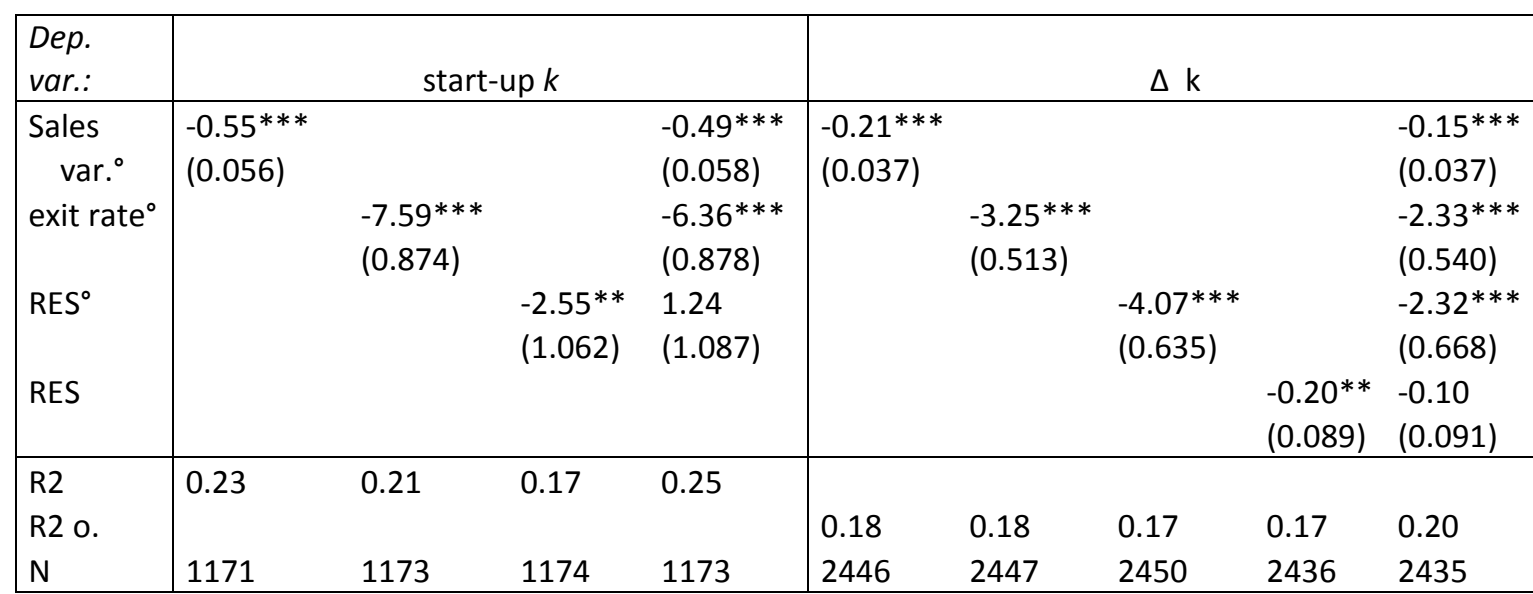

Source: Authors' calculation based on the ENAHO panel-subsample.

Notes: Regressions include all additional explanatory variables which are contained in the main regressions of equation (6) and (7). In all regressions, we drop influential outliers according to the procedure explained in the note to Table $3 .^{+++}$Variable is measured at the sector level. Robust standard errors in parenthesis $* p<0.10, * *$ $\mathrm{p}<0.05, * * * \mathrm{p}<0.01$. . 
Table A4: Estimated functions of start-up capital and accumulation with industry dummies

\begin{tabular}{|c|c|c|c|}
\hline Dependent variable: & start-up $k$ & $\Delta k$ & \\
\hline Log capital & & $\begin{array}{l}-0.554 * * * \\
(0.022)\end{array}$ & $\begin{array}{l}-0.555^{* * *} \\
(0.022)\end{array}$ \\
\hline Wealth index & $\begin{array}{l}0.199 * * * \\
(0.028)\end{array}$ & $\begin{array}{l}0.157 * * * \\
(0.016)\end{array}$ & $\begin{array}{l}0.181 * * * \\
(0.020)\end{array}$ \\
\hline Risk index & $\begin{array}{l}-0.140 * * \\
(0.065)\end{array}$ & $\begin{array}{l}-0.129 * * * \\
(0.033)\end{array}$ & $\begin{array}{l}-0.109 * * * \\
(0.040)\end{array}$ \\
\hline Wealth * Risk & $\begin{array}{l}0.045^{* *} \\
(0.018)\end{array}$ & $\begin{array}{l}0.026 * * \\
(0.010)\end{array}$ & $\begin{array}{l}0.028 * * * \\
(0.010)\end{array}$ \\
\hline Enterprise age & & $\begin{array}{l}-0.025 * * * \\
(0.009)\end{array}$ & $\begin{array}{l}-0.023 * * * \\
(0.009)\end{array}$ \\
\hline Enterprise age^2 & & $\begin{array}{l}0.001 * * \\
\left(2.5 * 10^{\wedge}-4\right)\end{array}$ & $\begin{array}{l}4.5^{*} 10^{\wedge}-4 * \\
\left(2.5^{*} 10^{\wedge}-4\right)\end{array}$ \\
\hline TFP & & $\begin{array}{l}0.263 * * * \\
(0.061)\end{array}$ & $\begin{array}{l}0.267 * * * \\
(0.061)\end{array}$ \\
\hline Enterprise age $*$ risk & & & $\begin{array}{l}-0.002 \\
(0.003)\end{array}$ \\
\hline Enterprise age * wealth & & & $\begin{array}{l}-0.003^{* *} \\
(0.001) \\
\end{array}$ \\
\hline Year dummies & Yes & Yes & Yes \\
\hline Industry dummies & Yes & Yes & Yes \\
\hline Outlier controlled $^{+}$ & Yes & Yes & Yes \\
\hline R2 & 0.382 & & \\
\hline R2 overall & & 0.241 & 0.246 \\
\hline $\mathrm{N}$ & 1170 & 2432 & 2426 \\
\hline
\end{tabular}

Source: Authors' calculation based on the ENAHO panel-subsample.

Notes: Regressions include all variables stated under Table $4 .{ }^{+}$In all regressions, we drop influential outliers according to the procedure explained in a note to Table 3 . Industry dummies represent all industries as in Table 3 with petty trading as baseline. Robust standard errors in parenthesis $* p<0.10, * * p<0.05, * * * p<0.01$ 
Figure 1: Capital accumulation and reduction of young firms over time (sub-sample)

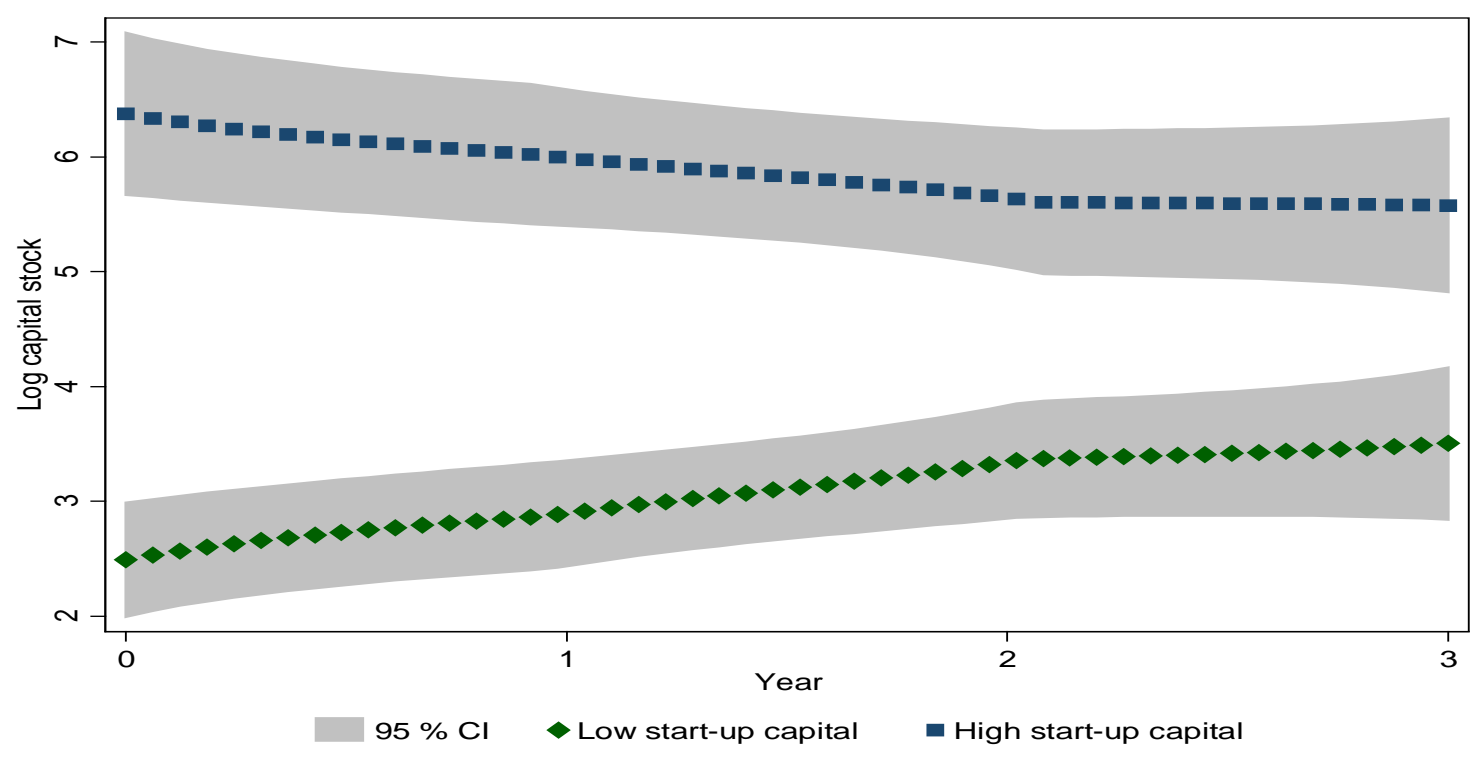

Source: Authors' calculation based on the ENAHO panel-subsample.

Notes: The figure is based on a sub-sample including only young firms with a maximum age of three years old when first observed and that are observed in at least four periods. 
Figure 2: Marginal returns for firms with an interquartile capital stock (p75 - p25)

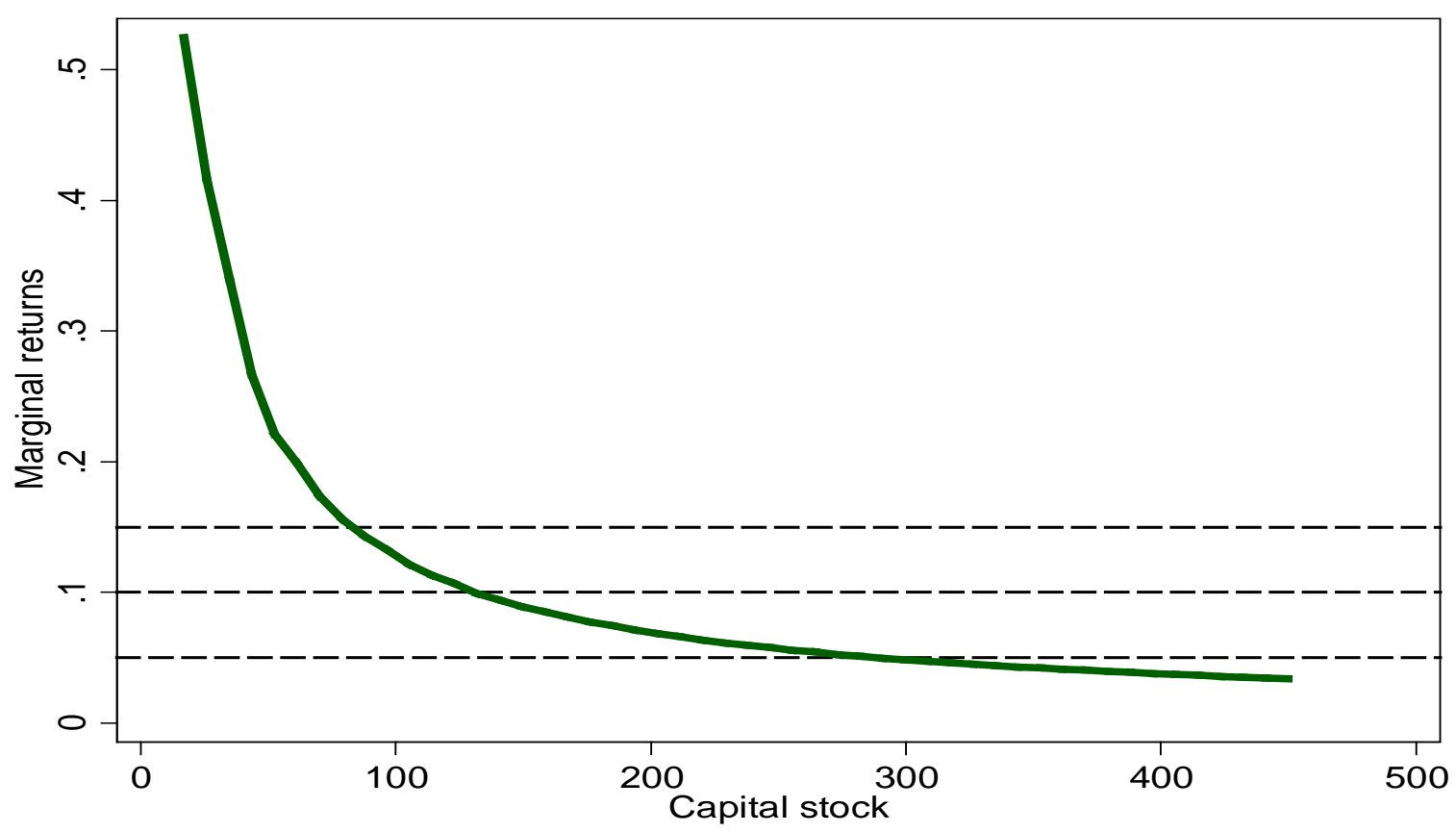

Source: Authors' calculation based on the ENAHO panel-subsample.

Notes: Marginal returns at lower than p25 capital stocks are very high which would imply a wide y-axis scaling. In contrast, they are close to zero for higher capital stocks, and a maximum value of 32,000 USD would imply a wide $x$-axis scaling. For a better graphical understanding, we choose to display only the interquartile range. We predict the profit level given the capital stock and mean values in all other variables. Whereas the mean log labor is $\mathbf{5 . 3 4}$ for the whole sample, it is only 4.94 for firms with a capital stock in the first quartile of capital stock. This results in a slight overestimation the returns to capital at low levels. Returns to capital are proxied by $(\Delta \mathrm{Y} / \Delta \mathrm{K})$ with $\Delta \mathrm{X}=\mathrm{Xt}-\mathrm{Xt}-5$. Results are robust to an extension of the lag length to 10 or 20 . 


\section{Figure A1: Descriptives}

Productivity, mean: 0 , sd: 0.56

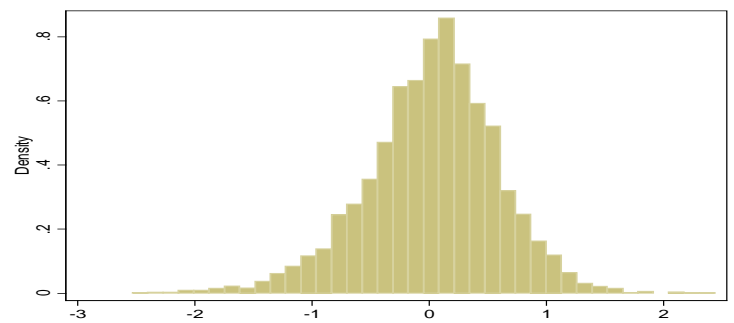

Risk, mean: 0, sd: 1.29

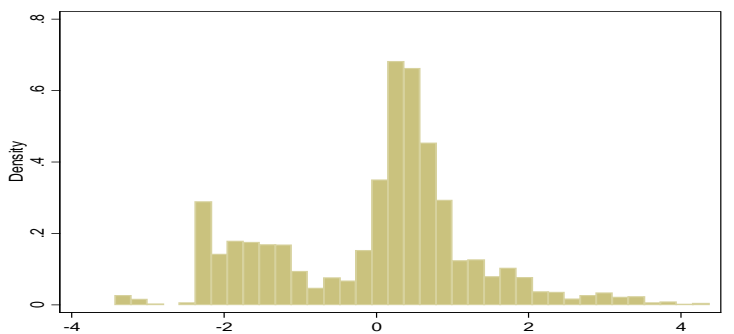

Wealth, mean: 0, sd: 2.06

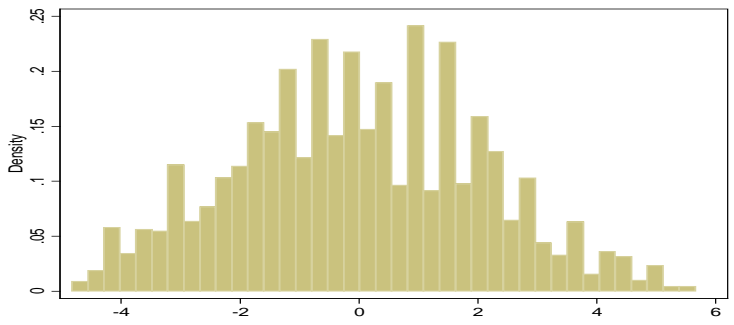

Initial risk, mean: 0, sd: 1.27

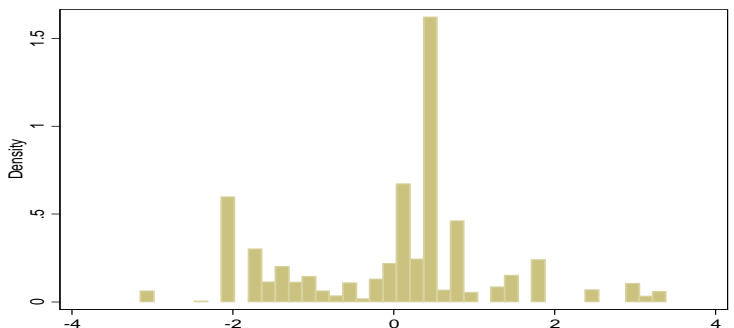




\section{Notes}

\footnotetext{
'Similar evidence (for selected groups of entrepreneurs) is provided by Fafchamps et al. (2011).

ii McPherson (1996) and Coad and Tamvada (2012), for example, show similar patterns for southern African and Indian firms, respectively.

iii Fajnzylber et al. (2006) do present some suggestive evidence in favor of credit constraints. The authors
} regress employment growth on dummies for credit at start-up, and dummies for subsequent credit (and a set of other controls). Firms with start-up credit appear to grow slower given that they reach their optimal capital stocks more rapidly. In contrast, MEs with subsequent access to credit grow faster, as they can quickly adjust to their optimal capital stock. Yet, the authors acknowledge that this result might be driven by simultaneity.

${ }^{i v}$ Further evidence for credit constraints is derived from exogenous (liquidity or credit availability) shocks on firm performance. Tybout (1983), for example, uses industry level data from Colombia. While favorable earnings shocks appear to be little relevant for large firms, these additional internal funds are used for investment by smaller firms. Banerjee and Duflo (2004) take advantage of a policy change in India that affected the flow of directed credit to estimate the effect of a favorable credit shock on investment and productivity of medium-sized firms. Their results show a large acceleration in the rate of growth of sales and profits due to the shock. In contrast, Akoten, Sawada, and Otsuka (2006) cannot find a positive impact of credit access on the performance of small garment producers in Kenya.

v Using data from the manufacturing sector in six African countries, Bigsten et al. (2003), for example, provide evidence that micro and small firms are much less likely to get a loan than large firms.

${ }^{v i}$ The World Bank's Doing Business dataset provides some information on credit availability as well as on the efficiency of contract enforcement (http://www.doingbusiness.org/). Whereas the percentage of individuals and firms listed by a private credit bureau amounts to 36 percent in Peru, it is 5 percent in Sub-Saharan Africa, 34 percent in Latin America, and 64 percent in OECD countries. The cost of contract enforcement amount to 36 percent of a claim in Peru, compared to 50 percent in Sub-Saharan Africa, 31 percent in Latin America and 20 percent in OECD countries.

${ }^{\text {vii }}$ A related explanation for low accumulation is the lack of self-control, another behavioral patterns that has been observed in low income countries (Fafchamps et al., 2011; de Mel et al., 2012).

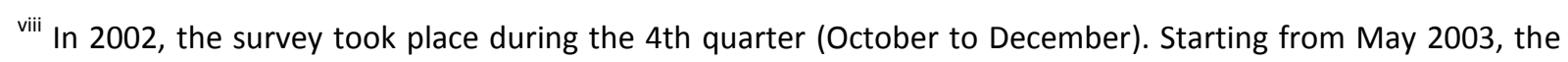
survey is permanent (the whole sample is distributed monthly along the year). Around 18 percent of the visited 
households are not interviewed as the household refuses, is absent, the house is unoccupied or other reasons (miscellaneous category). This leads to an unbalanced panel with 719, 1435, 1153, 1870 and 2096 households being observed in one, two, three, four and five years, respectively. The fact that this number is increasing reflects increased effort by INEI to create a larger panel dataset. Quite a number of panel households were not interviewed in consecutive years.

${ }^{\text {ix }}$ In urban areas, 10 percent of self-employed individuals work in agriculture, livestock production, or forestry, and are consequently not included in the Informal Sector Module.

${ }^{x}$ All monetary values are converted into 2001 USD. See Notes of Table 2 for details. Value-added is the value of monthly sales plus self-consumed production minus expenses other than on labor and capital (i.e. expenses for intermediate inputs and electricity).

${ }^{x i}$ We identify the firms by their owner. If a business is handed over from the owner to his wife, for example, this will be counted as business closure and opening. Consequently, our entry and exit rates may only be taken as an upper bound. However, these numbers are similar to those in Mead and Liedholm (1998) who find entry and exit rates in Sub-Sahara Africa ranging from 20-32 percent. Entry rates in their study are computed by dividing all new firms appearing in a given year by the number of firms in existence at the beginning of that year. Exit rates rely on retrospective information regarding business closure in the past year.

${ }^{\text {xii }}$ More precisely, we follow Banerjee and Munshi (2004) by regressing the logarithm of capital on a full set of year dummies. We then plot the residual of this regression plus the mean value against time using local polynomial smoothing based on an epanechnikov kernel.

xiii In the following, all monetary values are in 2001 USD (see Note under Table 2).

${ }^{\text {xiv }}$ Westbrook and Tybout (1993), for example, analyze returns to scale in firms that are observed in up to 8 years and have at least 10 employees in Chile. They find OLS log labor and log capital coefficients in most industries to be in the range between 0.7 and 0.9 , and 0.2 and 0.3 , respectively. Their within-plant estimates are in the range between 0.4 and 0.6 , and 0.1 and 0.3 , respectively. The authors argue that their OLS estimates appear to suffer from an upward bias while their within-plant estimates are likely to be downward biased, and identify measurement error in capital stocks to drive the latter result. This problem is certainly acerbated in our dataset covering microenterprises with fewer periods and up to 10 employees.

${ }^{x v}$ The average $T_{i}$ is 3.3 . 
xvi Using instead the time-variant residual from a RE model does not change the results.

xvii Only entrepreneurs that are observed in the subsequent period can be classified as exiting or surviving, i.e. we do not have this information for the last round of the surveys and entrepreneurs in households that were dropped from the panel.

xviii Here, the risk index does not contain the idiosyncratic measure as it is only available for new firms that are observed in at least two periods. This would reflect a strong selection and reduce our sample by two thirds.

${ }^{\text {xix }}$ In section 5.1, we explain why we believe the RE model to be the best choice despite a potential bias due to the individual effect. Similarly, dynamic panel models may be biased if the individual effect is correlated with the control variables. However, our key variables are all time invariant, which makes FE-estimation, for example applying a bias-corrected least-squares dummy variable estimator (LSDV), not feasible.

${ }^{x x}$ This numbers hold for firms with mean values. As wealth and risk are normalized the interaction term rules out.

${ }^{x \times i}$ If MEs with a high capital stock are more likely to tolerate productivity shocks and remain in business, the capital coefficient would be biased downwards. Firms with a low capital stock that experience an adverse shock may move out of business while those with a higher capital stock react by reducing capital. This would imply an upward bias in the growth rate of small firms as only surviving firms are considered.

${ }^{x x i i}$ Without $I S_{i t}$, identification relies on the nonlinearity of the inverse Mill's ratio. We have used a number of alternative instruments (including the number of household members, number of wage earners, transfer incomes, household composition variables, loss of employment, severe illness, criminal act or natural disaster). However, all of these variables are either not significant in the selection equation, or highly significant in the production function regression (after including the inverse mill ratio).

xxiii Sectors are disaggregated as finely as possible which means that they are not equivalent to common industry definitions (see for example Table 3).

${ }^{\text {xxiv }}$ Other coefficients are not affected by the inclusion of sectoral dummies. 